Federal Reserve Bank of Minneapolis

Research Department

\title{
TAX DISTURBANCES AND REAL ECONOMIC ACTIVITY IN THE POSTWAR UNITED STATES
}

\author{
R. Anton Braun
}

Working Paper 506

November 1992

\begin{abstract}
This paper investigates the macroeconomic effects of cyclical fluctuations in marginal tax rates. It finds that systematically including tax variables in a standard real business cycle model substantially improves the model's ability to reproduce basic facts about postwar U.S. business cycle fluctuations. In particular, modeling fluctuations in personal and corporate income tax rates increases the model's predicted relative variability of hours and decreases its predicted correlation between hours and average productivity. Fluctuations in tax rates produce large substitution effects that alter the leisure/labor supply decision.
\end{abstract}

*Federal Reserve Bank of Minneapolis and University of Virginia. I have received helpful comments from seminar participants at Carnegie Mellon University, the NBER Summer Institute on Economic Fluctuations, the University of Rochester, the University of Virginia, and the University of Western Ontario. I owe particular thanks to my advisor, Martin Eichenbaum.

The views expressed herein are those of the author and not necessarily those of the Federal Reserve Bank of Minneapolis or the Federal Reserve System. 


\section{Introduction}

Are movements in taxes important sources of cyclical variation in postwar U.S. data? This study provides evidence that the answer is, yes, taxes are quite important. In the course of making this point, I solve two empirical puzzles.

One puzzle concerns the correlation of wages and employment. Work on postwar U.S. data by Bodkin (1969), Geary and Kennan (1982), and Barsky and Solon (1989) finds that wages and employment are roughly uncorrelated. These results are at odds with real business cycle models, which predict a strong positive correlation between wages, as measured by average productivity, and hours worked. Real business cycle models typically have a single shock to average productivity. [See, for example, Kydland and Prescott (1982) or Long and Plosser (1983).] In such a model, variations in technology act primarily to shift labor demand along a stable labor supply curve, thus inducing a strong positive correlation between wages and hours.

This line of reasoning suggests that the missing ingredient in real business cycle models is something that shifts labor supply. If both labor demand and labor supply shift, then the strong positive correlation between wages and hours can probably be reduced. Several candidate labor supply shifters have already been considered: home production, by Benhabib, Rogerson, and Wright (1991); unobservable shocks to preferences, by Bencivenga (1992); and government consumption, by Christiano and Eichenbaum (1992).

Here the focus is on two other candidates: transient movements in tax rates on both personal income and capital income. Both of these types of tax changes alter the leisure/labor supply decision. A transient fall in the effective tax rate on capital 
income increases the after-tax interest rate, which leads agents to work more today and consume more leisure tomorrow. A fall in the wage tax also increases labor supply. The rise in the after-tax wage induces an intratemporal substitution effect which leads agents to work more today, while the wage rate is high.

Both forms of taxes are potential labor supply shifters, but have their historical movements actually been great enough to offset the positive impulses produced by shocks to average productivity? Yes. When fluctuating tax rates are combined with shocks to productivity in a real business cycle model economy, it predicts a weak negative correlation between the first-difference of average productivity and hours that is close to the value measured in the postwar U.S. data.

The other empirical puzzle I confront here concerns the relative variability of hours worked and output, which most real business cycle models understate. One solution to this puzzle is to model indivisibilities in labor. G. Hansen (1985), for instance, captures the empirical volatility of hours in a model where agents either work a fixed number of hours or are unemployed. An implication of Hansen's specification, however, is that those who are unemployed are better off than those who work. [See Rogerson and Wright (1988) for a discussion of this implication and specifications that avoid it.l The divisible-labor specification presented here also captures the observed relative volatility of hours to output.

In addition to these two particular moments, I use a variety of diagnostics to evaluate the performance of the taxed economy along broader dimensions. These diagnostics suggest that the second-moment properties of the taxed economy compare favorably with the performance of a more traditional real business cycle model. 
Taxes are found to be particularly important for understanding the comovements of hours with other aggregate variables.

My study adds to other recent work on the role of fluctuations in tax variables as sources of economic fluctuations. Chang (1992) focuses on the implications of the differential tax treatment of equipment and structures and finds that movements in effective tax rates on capital amplify fluctuations in investment. McGrattan (1991) estimates a specification similar to mine using maximum likelihood and investigates the cyclical properties and welfare costs associated with stochastic fluctuations in distortionary taxes. In addition, several recent papers have considered issues related to welfare costs of alternative tax programs in a stochastic environment. See, for example, Bizer and Judd (1989); Cassou (1990); Chari, Christiano, and Kehoe (1991); Cooley and Hansen (1991); and Greenwood and Huffman (1991) as well as Chang and McGrattan.

The paper is organized straightforwardly. Section 2 describes the model; section 3 outlines the estimation strategy and summarizes the estimation results; and section 4 discusses the second-moment properties of the model and compares them to those of an economy in which all taxation is lump sum. Section 5 concludes.

\section{The model}

Consider a collection of households who derive utility, $u$, from consumption, $c_{t}$, and leisure, $l_{t}$. Assume that household preferences over consumption and leisure can be represented by

$$
E_{0}\left\{\sum_{i=0}^{\infty} \beta^{\mathrm{h}} \mathrm{u}\left(\mathrm{c}_{\mathrm{t}}, \mathrm{l}_{\mathrm{t}}\right)\right\},
$$


where

$$
\begin{aligned}
& \mathrm{c}_{\mathrm{t}}=\mathrm{cp}_{\mathrm{t}}+\gamma_{1} \mathrm{G}_{\mathrm{t}}, \\
& \mathrm{T}=\mathrm{n}_{\mathrm{t}}+\mathrm{l}_{\mathrm{t}},
\end{aligned}
$$

and $\beta$ is the discount rate. In this formulation, households have preferences over both private consumption, $\mathrm{CP}_{\mathrm{l}}$, and government consumption, $\mathrm{G}_{\mathrm{l}}$, which is assumed to be uncontrollable by households. The substitutability properties of private and government consumption are governed by the preference parameter, $\gamma_{1}$. (Capital letters denote aggregate quantities expressed in per-capita terms.) Each household's total allocation of time, $\mathrm{T}$, is divided between leisure activities and labor, $\mathrm{n}_{\mathrm{t}}$.

The representative household's wealth evolves according to

$$
c p_{\mathfrak{t}}+k_{t+1} \leq k_{t}+\left(1-\tau_{\mathfrak{v}}\right) w_{t} n_{t}+\left(1-\tau_{\mathfrak{t}}\right)\left(1-\tau \kappa_{\mathfrak{t}}\right)\left(\mathrm{r}_{\mathrm{t}}-\delta\right) \mathrm{k}_{\mathrm{t}}+\mathrm{TR}_{\mathrm{t}}
$$

Here $k_{t}$ is the household's holdings of the capital good which is rented to firms, $r_{t}$ is the pretax rental rate on capital, $\delta$ is the depreciation rate on capital, $\mathrm{TR}_{\mathrm{t}}$ is the time $\mathrm{t}$ government transfer to the household, $\mathrm{w}_{\mathrm{t}}$ is the time $\mathrm{t}$ wage rate, and $\tau_{\mathrm{t}}$ and $\tau \kappa_{\mathrm{t}}$ are the time $t$ marginal tax rates on personal income and capital income.

This specification of taxes reflects the double taxation of capital income built into the U.S. Tax Code, but the specification may overstate the overall tax on capital income. For instance, the capital stock includes durable consumption goods which are taxed at the corporate, but not the personal, level. To examine the role of this assumption, I will also analyze what happens when $\left(1-\tau_{\mathcal{v}}\right)$ enters the model only on labor income. 
In this economy, output, $\mathrm{Y}_{\mathrm{t}}$, is produced by competitive firms using a constant returns to scale production technology:

$$
Y_{t}=F\left(K_{t}, N_{t}, z_{t}\right)
$$

where $K_{t}$ denotes capital input and $N_{t}$ denotes labor input. The final argument of the production technology, $z_{t}$, is a shock to average productivity. This shock is assumed to exhibit stochastic growth:

$$
\ln \left(\mathrm{z}_{\mathrm{t}}\right)=\ln \left(\mathrm{z}_{\mathrm{t}-1}\right)+\ln \left(\lambda_{\mathrm{t}}\right)
$$

where $\lambda_{t}$ is a stationary random variable. Aggregate allocations must satisfy this feasibility condition:

$$
\mathrm{K}_{\mathrm{t}+1} \leq(1-\delta) \mathrm{K}_{\mathrm{t}}+\mathrm{Y}_{\mathrm{t}}-\mathrm{G}_{\mathrm{t}}-\mathrm{CP}_{\mathrm{t}}
$$

To complete the specification of the economic environment, I must specify the government's actions. The government's time $t$ budget constraint is

$$
\tau_{\mathrm{t}} \mathrm{W}_{\mathrm{t}} \mathrm{N}_{\mathrm{l}}+\left(\tau_{\mathrm{t}}+\tau \kappa_{\mathrm{t}}-\tau_{\mathrm{t}} \tau \kappa_{\mathrm{t}}\right)\left(\mathrm{r}_{\mathrm{t}}-\delta\right) \mathrm{K}_{\mathrm{t}} \geq \mathrm{G}_{\mathrm{t}}+\mathrm{TR}_{\mathrm{t}}
$$

Here I take no position on the nature of the government's objective function. Instead, I use historical data to develop a statistical model of the feedback rule used by the government. Exercises of this sort have been proposed and analyzed by Sargent (1984). To capture the empirical characteristics of government policy, assume that the vector process $\left\{\tilde{\mathrm{G}}_{\mathrm{l}}, \tau_{\mathrm{t}}, \tau \kappa_{\mathrm{t}}, \lambda_{\mathrm{l}}\right\}$ is stationary and ergodic and has this autoregressive representation: 


$$
\left[\begin{array}{l}
\ln \left(\tau_{\mathrm{t}}\right) \\
\ln \left(\tau \kappa_{\mathrm{t}}\right) \\
\ln \left(\tilde{\mathrm{G}}_{\mathrm{t}}\right) \\
\lambda_{\mathrm{t}}
\end{array}\right]=\mathrm{B}_{0}+\mathrm{B}(\mathrm{L})\left[\begin{array}{l}
\ln \left(\tau_{\mathrm{t}-1}\right) \\
\ln \left(\tau \kappa_{\mathrm{t}-1}\right) \\
\ln \left(\tilde{\mathrm{G}}_{\mathrm{t}-1}\right) \\
\lambda_{\mathrm{t}-1}
\end{array}\right]+\left[\begin{array}{l}
\nu_{\mathrm{tt}} \\
\nu_{2 \mathrm{t}} \\
\epsilon_{\mathrm{t}} \\
\mu_{\mathrm{t}}
\end{array}\right],
$$

where $\tilde{G}_{\mathrm{t}}=\mathrm{G}_{\mathrm{t}} / \mathrm{z}_{\mathrm{t}}$. The innovations $\nu_{\mathrm{lt}}, \nu_{2 t}$, and $\epsilon_{\mathrm{t}}$ are assumed to be stationary and ergodic with the variance-covariance matrix $\mathrm{V}$ which satisfies $\operatorname{det}(\mathrm{V})<\infty$. Implicit in this specification are the assumptions that marginal tax rates are stationary in levels and government consumption is first-difference stationary and has a common trend with $z_{\imath}$. Finally, given this description of the evolution of taxes and government purchases, transfers are determined by eq. (8).

The equilibrium quantities for this economy will not correspond to Pareto optimal allocations because of the well-known incentive effects associated with the distortionary taxation of income. Consequently, the social planner's problem cannot be used to calculate the economy's equilibrium allocations. Instead, the competitive equilibrium will be calculated directly by solving log-linearized versions of noarbitrage restrictions that hold in equilibrium.

To derive these restrictions, observe that the first-order necessary conditions for the household's problem are

$$
\begin{aligned}
& \mathrm{u}_{1}\left(\mathrm{c}_{\mathrm{t}}, \mathrm{l}_{\mathrm{l}}\right)-\mu_{1 \mathrm{t}}=0, \\
& -\mathrm{u}_{2}\left(\mathrm{c}_{\mathrm{t}}, \mathrm{l}_{\mathrm{t}}\right)+\mu_{1 \mathrm{t}}\left(1-\tau_{\mathrm{t}}\right) \mathrm{w}_{\mathrm{t}}=0, \\
& -\mu_{1 \mathrm{t}}+\beta \mathrm{E}\left[\mu_{1 \mathrm{lt}+1}\left\{\left(1-\tau_{\mathrm{t}+1}\right)\left(1-\tau \kappa_{\mathrm{t}+\mathrm{i}}\right)\left(\mathrm{r}_{\mathrm{t}+1}-\delta\right)+1\right\}\right]=0,
\end{aligned}
$$

where the notation $u_{i}\left(c_{t}, l_{t}\right)$, for $i=1,2$, is used to denote the derivative of the period $t$ utility function with respect to its ith argument. Substitution of (10) into (11) and 
(12) produces two familiar restrictions: one equating the marginal rate of substitution of consumption and leisure to the after-tax real wage, the other relating the intertemporal rate of marginal substitution to the after-tax interest rate. The first-order necessary conditions for the firm's problem imply these marginal product pricing relationships:

$$
\begin{aligned}
& \mathrm{r}_{\mathrm{t}}=\mathrm{F}_{\mathrm{l}}\left(\mathrm{K}_{\mathrm{t}}, \mathrm{N}_{\mathrm{t}}, \lambda_{\mathrm{t}}\right), \\
& \mathrm{w}_{\mathrm{t}}=\mathrm{F}_{2}\left(\mathrm{~K}_{\mathrm{t}}, \mathrm{N}_{\mathrm{t}}, \lambda_{\mathrm{t}}\right) .
\end{aligned}
$$

In equilibrium, $n_{t}=N_{t}$ and $k_{t}=K_{t}$. These facts imply two arbitrage conditions:

$$
\begin{aligned}
& \mathrm{u}_{1}\left(\mathrm{c}_{1}, \mathrm{l}_{\mathrm{l}}\right)\left(1-\tau_{\mathrm{v}}\right) \mathrm{F}_{2}\left(\mathrm{~K}_{\mathrm{t}}, \mathrm{N}_{\mathrm{t}}, \lambda_{\mathrm{t}}\right)=-\mathrm{u}_{2}\left(\mathrm{c}_{\mathrm{t}}, \mathrm{l}_{\mathrm{l}}\right), \\
& \mathrm{E}_{\mathrm{t}}\left(\beta \mathrm{u}_{1},\left(\mathrm{c}_{\mathrm{t}+1}, \mathrm{l}_{\mathrm{t}+1}\right)\left\{\left(1-\tau_{\mathrm{t}+1}\right)\left(1-\tau \kappa_{\mathrm{t}+1}\right)\left[\mathrm{F}_{1}\left(\mathrm{~K}_{\mathrm{t}+1}, \mathrm{~N}_{\mathrm{t}+1}, \lambda_{\mathrm{t}+1}\right)-\delta\right]+1\right\}\right) \\
& \quad=\mathrm{u}_{1}\left(\mathrm{c}_{\mathrm{t}}, \mathrm{l}\right) .
\end{aligned}
$$

Before proceeding further, I must confront the growth that is inherent in the economy specified in eqs. (1)-(16). Under the assumption that the growth rates of the productivity shock, capital, consumption, output, government consumption, and transfers are the same, Christiano (1988) and King, Plosser, and Rebelo (1988) define a transformation which removes this growth. They do this by defining an equivalent economy that is expressed in terms of a random vector:

$$
\left\{c_{\mathrm{l}} / \mathrm{z}_{\mathrm{t}}, \mathrm{n}_{\mathrm{l}}, \mathrm{i}_{\mathrm{l}} / \mathrm{z}_{\mathrm{t}}, \mathrm{k}_{\mathrm{t}} / \mathrm{z}_{\mathrm{t}-1}, \mathrm{G}_{\mathrm{t}} / \mathrm{z}_{\mathrm{l}-1}, \mathrm{TR}_{\mathrm{t}} / \mathrm{z}_{\mathrm{l}}, \mathrm{w}_{\mathrm{t}} / \mathrm{z}_{\mathrm{t}}\right\}
$$

Under this assumption, transformed versions of eqs. (15) and (16) in conjunction with transformed versions of eqs. (3), (5), and (7) implicitly define a sequence of allocations for capital, consumption, employment, output, and leisure. 
Due to the large number of state variables, the model's equilibrium is calculated by solving a $\log$-linear approximation to these market-clearing conditions. This sequence is calculated by taking a log first-order Taylor expansion about these equations centered at the perfect-foresight steady state. The resulting linear system is then solved using a nonrecursive algorithm due to Vaughn (1970) as implemented by King, Plosser, and Rebelo (1988). The allocations calculated in this way can be supported as a competitive equilibrium using the pricing relations given in (13) and (14). (Further details on the linearization and solution of the model are available from the author on request.)

\section{Estimation of the model}

The model economy just described offers predictions for the evolution of aggregate consumption, investment, hours worked, real wages, and the capital stock given a specification of government policy and technology. This section describes how I estimate the government's feedback rule and the most important preference and technology parameters.

Before turning to a discussion of the estimation, I will briefly document the data set used in this analysis. The model is estimated using annual data. The choice of annual data is motivated by the measures of marginal tax rates, which are only available annually. Tax rates probably vary little over the course of a year, however, so the strongest comovements are likely to occur at annual frequencies. The marginal tax on personal income, $\tau_{\mathrm{t}}$, is measured using Barro and Sahasakul's (1983) time series on average marginal tax rates. This time series is constructed by averaging tax rates over numbers of returns for each class of adjusted gross income. The marginal 
tax rate on corporate capital income, $\tau \kappa_{\mathrm{t}}$, is measured using Jorgenson and Sullivan's (1981) effective tax rate.

Many of the other annual time series are averages of quarterly data constructed by Christiano (1988), who decomposes government purchases into investment and consumption categories. Private consumption includes consumption of nondurables and services plus an imputed service flow from the stock of durables. Government consumption includes purchases of goods and services of all levels of government less a measure of investment based on Musgrave's (1980) estimates of the stock of government capital. Gross investment includes government fixed investment, private fixed investment, and expenditures on durables. The capital stock is chosen to be consistent with the gross investment time series. Output, then, is private consumption plus investment plus government consumption. A comprehensive description of the sources used in constructing this data set can be found in Christiano $(1987,1988)$.

My measure of labor input is employee hours in nonagricultural establishments (Citibase file LPMHU). The real wage series was constructed using data on compensation of employees in the nonfarm business sector (Citibase file GCOMP). All time series are expressed in per-capita terms based on male and female population aged 20-64 from the U.S. Bureau of the Census.

The structural parameters were estimated using L. P. Hansen's (1982) generalized method of moments (GMM) estimator. This estimator provides consistent and efficient instrumental variable estimates of the structural parameters under general assumptions about the distribution of the endogenous variables and the forcing processes. One of the more important maintained assumptions underlying my 
estimation is the assumption that the random vector $\left\{\tau_{t}, \tau \kappa_{t}, N_{t}, w_{t} / C_{t}, Y_{t} / K_{t}, C_{t} / C_{t+1}\right.$, $\left.\mathrm{G}_{\mathrm{t}} / \mathrm{z}_{\mathrm{t}}\right\}$ is stationary and ergodic.

To estimate the model, I must take an explicit position on the functional form of technology and preferences. Technology will be assumed to be Cobb-Douglas:

$$
\mathrm{Y}_{\mathrm{t}}=\mathrm{K}_{\mathrm{t}}^{\theta}\left(\mathrm{N}_{\mathrm{t}} \mathrm{z}_{\mathrm{t}}\right)^{1-\theta},
$$

where $\theta$ is the capital share parameter, and preferences will be assumed to be logarithmic:

$$
\mathrm{u}\left(\mathrm{c}_{\mathrm{t}}, \mathrm{l}_{\mathrm{t}}\right)=\ln \left(\mathrm{c}_{\mathrm{t}}\right)+\gamma_{2} \ln \left(\mathrm{T}-\mathrm{n}_{\mathrm{t}}\right),
$$

where $\gamma_{2}$ is the leisure share parameter.

The following unconditional-moment conditions were used to estimate the parameter vector $\pi=\left(\theta, \bar{\lambda}, \sigma_{\mu}, \gamma_{2}, \bar{\tau}, \overline{\tau \kappa}, \rho, \alpha, \varphi_{0}, \varphi_{1}, \mathrm{~V}\right)$ :

$$
\begin{aligned}
& \mathrm{E}\left[\frac{\gamma_{2}}{\mathrm{~T}-\mathrm{N}_{\mathrm{t}}}-\frac{\left(1-\tau_{\mathrm{t}}\right) \mathrm{w}_{\mathrm{t}}}{\mathrm{CP}{ }_{\mathrm{t}}+\gamma_{1} \mathrm{G}_{\mathrm{t}}}\right]=0, \\
& \mathrm{E}\left[\frac{1}{\mathrm{C}_{\mathrm{t}}}-\frac{\beta\left[1+\left(1-\tau_{\mathrm{t}+1}\right)\left(1-\tau \kappa_{\mathrm{t}+1}\right)\left(\theta \mathrm{Y}_{\mathrm{t}+1} / \mathrm{K}_{\mathrm{t}+1}-\delta\right)\right]}{\mathrm{C}_{\mathrm{t}+1}}\right]=0, \\
& \mathrm{E}\left(\ln \left(\mathrm{y}_{\mathrm{t}} / \mathrm{y}_{\mathrm{t}-1}\right)-\bar{\lambda}\right)=0, \\
& \mathrm{E}\left(\tau_{\mathrm{t}}-\bar{\tau}\right)=0, \\
& \mathrm{E}\left(\ln \left(\tau_{\mathrm{t}}-\bar{\tau}\right)-\rho \ln \left(\tau_{\mathrm{t}-1}-\bar{\tau}\right)\right) \ln \left(\tau_{\mathrm{t}-1}-\bar{\tau}\right)=0, \\
& \mathrm{E}\left(\tau \kappa_{\mathrm{t}}-\overline{\tau \kappa}\right)=0, \\
& \mathrm{E}\left(\ln \left(\tau \kappa_{\mathrm{t}}-\overline{\tau \kappa}\right)-\alpha \ln \left(\tau \kappa_{\mathrm{t}-1}-\overline{\tau \kappa}\right)\right) \ln \left(\tau \kappa_{\mathrm{t}-1}-\overline{\tau \kappa}\right)=0,
\end{aligned}
$$




$$
\mathrm{E}\left(\ln \left(\mathrm{G}_{\mathrm{i}} / \mathrm{z}_{\mathrm{t}}\right)-\varphi_{0}-\varphi_{1} \ln \left(\mathrm{G}_{\mathrm{t}-1} / \mathrm{z}_{\mathrm{t}-1}\right)\right)\left(\begin{array}{c}
\ln \left(\mathrm{G}_{\mathrm{t}-1} / \mathrm{z}_{\mathrm{t}-1}\right) \\
1
\end{array}\right)=0
$$

where variables with overbars represent means. The first two moment conditions, (19) and (20), are the empirical counterparts of the arbitrage conditions, (15) and (16). In eq. (19), $w_{t}$ is measured using the compensation-based measure of the real wage described above. Notice further that, in the absence of some form of measurement error, (19) is an identity. A measurement error story consistent with (19) and the remaining moment restrictions is that real wages are subject to some measurement error proportionate to $\mathrm{w}_{\mathrm{t}}$. Eq. (21) is used to identify the mean growth rate of technology, $\lambda$, which under the null of the model is equal to the growth rate of output.

Eqs. (22)-(26) identify the parameters of the government's feedback rule. This specification was chosen after first estimating an unrestricted VAR(1) model of the two taxes, transformed government purchases, and the log first-difference of the Solow residual using annual data running from 1956 to 1980 . All variables insignificant at the $5 \%$ level were then constrained to be zero. Finally, note that the variance-covariance matrix of the innovations, $\mathrm{V}$, can be consistently estimated using the estimated residuals from eqs. (22), (24), and (26) and eq. (17) in conjunction with (6).

Three parameters were fixed in estimation: $\beta$, the discount rate; $\delta$, the depreciation rate on capital; and $\gamma_{1}$, the preference parameter governing substitutability of private and government consumption. I fixed $\beta$ at $(1.03)^{-1}$ and $\delta$ at 0.0834 and assigned $\gamma_{1}$ a value of 0.4 after efforts to identify $\gamma_{1}$ proved unsuccessful. The 
value of 0.4 was chosen because it lies in the range of values estimated by Kormendi (1983) and Aschauer (1985). Together these assumptions on the value of $\gamma_{1}$ and $\beta$, in conjunction with the moment conditions given by eqs. (19)-(26), exactly identify the parameter vector $\pi$.

In addition to the baseline specification given by eqs. (19)-(26), two other specifications are estimated. First, to investigate the role of my assumption about the double taxation of capital, the model is estimated with $\tau_{\mathrm{t}}$ in eq. (20) set to zero for all t. Second, to facilitate comparison with more traditional real business cycle models, which ignore the effects of distortionary taxation, a lump-sum tax version of the model is estimated. The moment conditions for this lump-sum specification are given by eqs. (19), (20), (21), and (26) with $\tau_{\mathrm{t}}$ and $\tau \kappa_{\mathrm{t}}$ set to zero for all t.

Table 1 displays the just-identified estimates of the structural parameters based on the orthogonality conditions (19)-(26) and the data set described above. The sample period runs from 1956 to 1980 . The standard errors were calculated using the Newey-West (1987) covariance estimator with three autocovariances. The first column of estimates, labeled lump-sum tax, corresponds to the specification that ignores the incentive-distorting effects of taxes on wage and capital income; the second column, to the specification that taxes capital income twice; and the third column, to the specification that taxes capital income only at the corporate level.

The results in table 1 have several notable features. First, the point estimates differ significantly across the tax and no-tax (lump-sum) specifications. The preference parameter on leisure, $\gamma_{2}$, is significantly larger when taxes are not modeled. Eichenbaum, Hansen, and Singleton (1988) estimate the value of $\iota$, which is linked to $\gamma_{1}$ by $\iota=1 /\left(1+\gamma_{1}\right)$, to lie between 0.14 and 0.18 . This range of values 
is substantially lower than the value of 0.33 , which is typically assigned to $\imath$ in calibration exercises. [See Prescott (1986).] The results presented in table 1 imply an estimate of $\iota=0.15$ for the no-tax specification and a value of 0.19 for the two tax specifications. Both numbers are close to the estimates reported by Eichenbaum, Hansen, and Singleton (1988).

A second feature of the results is the sensitivity of $\theta$, the capital share parameter, to the model of taxes. The value of $\theta$ is significantly higher in both specifications with distortionary taxes. This difference stems from eq. (20). In the no-tax specification, $\theta$ is set to equate the pretax return on capital to the marginal rate of substitution (MRS), whereas in both tax specifications, $\theta$ is chosen to equate the MRS with the after-tax return on capital. Since the empirical MRSs are the same across these two scenarios, $\theta$ must adjust.

An alternative strategy for identifying $\theta$ is to assign income categories in the national income and product accounts to each factor of production. Christiano (1988) notes that values of $\theta$ based on this alternative approach can range between 0.25 and 0.43 , depending on how income is assigned to the two factors. After allowing for sampling uncertainty, all three of my estimated values lie in the range reported by Christiano. Finally, note that the estimate of 0.45 for the double tax specification is close to McGrattan's (1991) estimate of 0.43. This specification implies an overall tax rate on capital income of 0.46 , which is close to McGrattan's average capital income tax of 0.50 .

Turning next to the estimates of the fiscal policy variables, notice first that the estimated autoregressive coefficient on the personal income tax rate is 0.95 , indicating considerable persistence in the income tax. The corporate tax on capital 
income displays much less persistence. The matrices at the bottom of table 1 report standard deviations and estimated correlations between the innovations. These matrices indicate strong contemporary correlations among fiscal policy surprises and with innovations to technology. For both tax specifications, expenditure surprises are positively related to revenue surprises. Furthermore, in all three specifications, the technology shock displays a strong negative correlation with the transitory component of government purchases. In the next section, I will document the role this correlation plays in matching the cyclical properties of government purchases. Finally, both tax specifications produce a negative correlation between technology surprises and effective corporate tax rates.

The just-identified estimates calculated here imply that the model's predictions for the steady-state output shares of capital, consumption, and government purchases are consistent with the sample averages of these objects in the data over the estimated sample. In the next section, I will augment the list of moment conditions with restrictions based on minimizing the discrepancy of various predicted second moments from their values in the data. Once these further moment conditions are added, the system is overidentified and the overidentifying moment restrictions can be formally tested.

\section{Evaluation of the model}

This section documents and analyzes the quantitative implications of fluctuations in taxes on fluctuations in economic activity. Fluctuations in distortionary taxes turn out to have significant effects on the quantitative properties of the model economy. They increase the predicted relative variability of hours and reduce the 
predicted correlation between hours and average productivity. I use impulse response analysis to investigate the economic mechanisms underlying these improvements.

\subsection{Predictions}

To determine the role of tax disturbances in economic fluctuations, the model economy was solved using each of the three estimated parameterizations. The solution procedure described in section 2 produces a set of log-linear decision rules governing the evolution of equilibrium allocations and the prices that support these allocations. With linear decision rules, population moments can easily be directly compared with the analogous moments in the data.

Tables 2 and 3 report a variety of second moments for the lump-sum model, the two tax models, and the U.S. data. All moments are expressed in terms of log growth rates. Consider first the last column in each table. These columns report sample second moments and standard errors based on a sample period running from 1956 to 1980 . The standard errors are calculated using a Newey-West covariance estimator with three lags. The first data column of each table reports the predicted population moments for the lump-sum taxation version of the model with the parameterization described in section 3. The third and fifth data columns of each table contain the corresponding predictions for the model with taxes under the two alternative assumptions about the taxation of capital income. The second, fourth, and sixth data columns of each table contain statistics that are asymptotically $\chi^{2}(1)$ distributed under the null hypothesis that the predicted moment in the relevant row equals the corresponding value in the final column. The numbers in parentheses are probability values. Test statistics of this form have been considered by Burnside, 
Eichenbaum, and Rebelo (1990) and Christiano and Eichenbaum (1992). At the bottom of each panel of both tables is an additional statistic. The maintained null underlying it is that all the moments equal the corresponding values in the final column of the table. (A complete description of the calculation of these test statistics is in the appendix to this paper.)

Consider first the moment columns of table 2. Note that the lump-sum tax version of the model understates the relative variability of hours and the standard deviation of output. These properties of standard real business cycle models have been the subject of considerable research. G. Hansen (1985) demonstrates, for instance, that an indivisible labor specification can solve the problem with hours, and Prescott (1986) suggests that fiscal policy may explain the one with output. A more surprising result for the lump-sum specification is its overstatement of the relative variability of consumption. This arises from fluctuations in government purchases which are a substitute for private consumption. Finally, note that the measured negative correlation between innovations to technology and government purchases documented in the last section helps capture the measured variability of government purchases. If this correlation is set to zero, the relative variability of government purchases rises to 2 on the basis of a higher predicted standard deviation of government purchases.

Turning to the results for the other two versions of the model, note that fluctuations in taxes have large effects on many of the model's implications for relative variabilities. Now the predicted variability of output nearly matches the standard deviation of output in the data and the relative variability of hours is much 
closer to the observed relative variability of hours. However, both tax specifications overstate the relative variability of investment more than the lump-sum version did.

One metric for investigating the significance of these observed differences across the three specifications is given by the chi-square statistics reported for each of them. The $\chi^{2}(1)$ statistics add further support to the claim that the most significant failures of the lump-sum version of the economy are its predictions for the relative variability of hours and consumption. These statistics suggest further that the tendency to overstate the relative variability of consumption continues to be a problem for the taxed economies as well. Finally, the $\chi^{2}(7)$ statistics at the bottom of the table suggest that all three models are missing important features of variability observed in the data.

Panel A of table 3 lists cross-correlations with output for the three specifications and the data. For these moments, the distinctions between the three specifications are less sharp. The main failure of the lump-sum specification is an overstatement of the correlation between average productivity and output. Both tax specifications are more successful in capturing this moment while performing about as well as the lump-sum specification in other respects. Overall, on the basis of the $\chi^{2}(5)$ statistics, all three specifications capture the main features of these moments.

However, panel B of table 3 displays more significant distinctions in the predictions for contemporaneous correlations with hours. Christiano and Eichenbaum (1992) have argued that the weak correlation between hours and average productivity in the standard (lump-sum) real business cycle model represents a significant puzzle for this type of model. This finding is borne out in panel B. The lump-sum specification dramatically fails to capture this correlation, while the two tax specifica- 
tions capture both its sign and its magnitude. The tax specifications are also more successful with the comovement of hours with government purchases. But all three specifications have difficulty with the correlation of hours and the capital stock. The $\chi^{2}(5)$ statistics at the bottom of the panel add further support to my contention that fluctuations in taxes are important for understanding the observed comovements of hours with other aggregate variables.

\subsection{Analysis}

Now I analyze these results. The sharpest distinction between the tax and the lump-sum tax versions of the model is their predictions for the relative variability of hours and the correlation of hours and average productivity. Why are the tax specifications so successful in capturing these moments? To try to answer that, consider the impulse response functions in fig. 1. They are for the specification with double taxation of capital. The dashed lines in fig. 1 are the responses of the model's economic and policy variables to a temporary $1 \%$ rise in the corporate profit tax. The solid lines are the responses of those variables to a temporary $1 \%$ rise in the personal income tax rate.

For the tax on capital income, the first-order effect of the innovation is to lower the after-tax interest rate. This produces an intertemporal substitution effect on labor supply. With the after-tax interest rate temporarily below its mean, households want to put off work effort until tomorrow. This intuition is borne out by the impulse responses: equilibrium work effort falls, and both the after-tax wage rate and average productivity rise initially in response to the innovation to the corporate tax rate. The intertemporal substitution effects induced by the fall in the 
after-tax interest rate are also responsible for the initial rise in consumption and fall in investment. These responses are consistent with the results of Judd (1987), who finds that a temporary decline in the tax on capital financed by increased borrowing produces a drop in consumption and a rise in saving. Finally, note that the magnitude of these responses is small. Government revenue only rises $0.2 \%$ and investment falls about the same amount.

Next consider a $1 \%$ rise in the tax rate on personal income. This surprise produces a much larger response in employment, which falls $0.4 \%$. The previous intertemporal substitution effect is now complemented by an intratemporal substitution effect which induces households to reduce current consumption and work effort. Households face not only a lower after-tax interest rate, but also a lower after-tax wage rate. The fall in equilibrium employment, in turn, raises average productivity in early periods, but then drops it below its steady-state value as the effects of the fall in investment are felt on capital. The strength of the intratemporal substitution effect can be observed in consumption, which now falls despite a substantial drop in investment. Finally, government revenue increases $0.4 \%$, which is about twice as much as it rose with the capital income tax increase.

The observation that both types of taxes shift labor supply explains the success of the two distortionary tax specifications in matching the relative variability of hours and the correlation of hours and average productivity. Christiano and Eichenbaum (1992) note that the first-order effect of technology shifts is to shift labor demand along an essentially stable labor supply schedule, thus producing a strong positive correlation between hours and the real wage. Fluctuations in government purchases also shift labor supply. However, the results in tables 2 and 3 suggest that 
historical movements in government purchases alone are not large enough. The specification with lump-sum taxation understates the relative variability of hours and predicts a large positive correlation between hours and average productivity. [These results are representative of those Christiano and Eichenbaum (1992) get when they assume labor input is correctly measured.] In contrast, tables 2 and 3 demonstrate that historical movements in taxes on capital and personal income have been large enough to explain both the observed variability in hours and the correlation of hours with average productivity.

\section{Concluding remarks}

This paper has presented evidence that the measured fluctuations in average marginal tax rates have important effects on the quantitative properties of a simple model economy of the business cycle. Incorporating taxes generally enhanced the empirical properties of the model, with the most striking improvements occurring in the labor market. The main exception was a tendency for versions of the model with taxes to overstate the relative variability of investment. The principal channels for these effects were found to be intertemporal and intratemporal substitution effects.

These documented substitution effects may seem inconsistent with much of the labor economics literature. For example, the preference parameters I used here imply a wage elasticity much higher than that found in the labor literature. My compensated wage elasticity [as calculated in Braun (1990)] ranges from 1.9 to 2.14; a summary of the labor literature [Burtless (1986)] reports an average wage elasticity for males of 0.28 . 
This is not an appropriate comparison, however. Much of the labor literature consists of static analyses that ignore human capital accumulation and the participation decision. When these decisions are modeled in a dynamic framework, as in Eckstein and Wolpin (1989), the responsiveness of labor supply to variations in current wage rates varies significantly over the life cycle. 


\section{Appendix: Testing sets of moment conditions}

Here I describe how I calculated the test statistics reported in section 4.

In testing the relative variabilities and correlations, I used the moment conditions described in section 3 and appended additional moment restrictions, introducing a new parameter for each new moment condition. For the relative variabilities, these were

$$
\begin{aligned}
& E\left[\ln \left(\mathrm{y}_{\mathrm{i}} / \mathrm{y}_{\mathrm{t}-1}\right)^{2}-\sigma_{\mathrm{m}, \mathrm{y}}^{2}-\nu_{\mathrm{l}}\right]=0, \\
& E\left[\left(\ln \left(\mathrm{y}_{\mathrm{l}} / \mathrm{y}_{\mathrm{t}-1}\right)-\lambda\right)^{2} \operatorname{lqmom}_{\mathrm{i}}-\left(\mathrm{x}(\mathrm{i}) \mathrm{f}^{2}-\nu_{\mathrm{i}}\right]=0, \quad \text { for } \mathrm{i}=2,7,\right.
\end{aligned}
$$

where

$$
\begin{aligned}
x_{t}= & {\left[\ln \left(\mathrm{cp}_{\mathrm{t}} / \mathrm{cp}_{\mathrm{t}-1}\right)-\lambda, \ln \left(\mathrm{n}_{\mathrm{t}} / \mathrm{n}_{\mathrm{t}-1}\right), \ln \left(\mathrm{dk}_{\mathrm{t}} / \mathrm{dk}_{\mathrm{t}-\mathrm{l}}\right)-\lambda,\right.} \\
& \left.\ln \left(\mathrm{y}_{\mathrm{t}} \mathrm{n}_{\mathrm{t}-1} /\left\{\mathrm{n}_{\mathrm{t}} \mathrm{y}_{\mathrm{t}-1}\right\}\right)-\lambda, \ln \left(\mathrm{k}_{\mathrm{t}} / \mathrm{k}_{\mathrm{t}-1}\right)-\lambda, \ln \left(\mathrm{g}_{\mathrm{t}} / \mathrm{g}_{\mathrm{t}-1}\right)\right] .
\end{aligned}
$$

In (A.1), $\sigma_{\mathrm{m}, y}^{2}$ is the model's predicted variance for output expressed in log growth rates. In (A.2), $x(i)_{t}$ denotes the ith element of the vector $x_{t}, \nu_{i}$ is a parameter that is estimated, and lqmom $_{\mathrm{i}}$ is the model's predicted population moment for the ith relative variance. All model moments and data moments are calculated in terms of deviations from $\lambda$, the mean of $\lambda_{t}$. After these new moment restrictions are appended to (19)-(26), the parameter vector $\bar{\pi}=\left[\pi, \nu_{1}, \ldots, \nu_{7}\right]$ is estimated using GMM. Then the null hypothesis I want to test is the joint restriction on $\bar{\pi}$ :

$$
\mathrm{a}(\tilde{\pi}) \equiv\left[0, \ldots, 0, \nu_{1}, \ldots, \nu_{6}\right]=0 .
$$

Newey and West (1987) propose the following statistic for testing restrictions of this form: 


$$
\operatorname{Na}\left(\tilde{\pi}_{N}\right)^{\prime}\left[A_{N}\left[\left(\frac{\partial g_{n}\left(\tilde{\pi}_{N}\right)}{\partial \tilde{\pi}}\right]^{\prime}\left(S_{w}^{N}\right)^{-1}\left(\frac{\partial g_{n}\left(\tilde{\pi}_{N}\right)}{\partial \tilde{\pi}}\right]\right]^{-1} A_{N}^{\prime}\right]^{-1} a\left(\tilde{\pi}_{N}\right),
$$

where

$$
\mathrm{A}_{\mathrm{N}}=\frac{\partial \mathrm{a}\left(\tilde{\pi}_{\mathrm{N}}\right)}{\partial \tilde{\pi}}
$$

and $S_{w}^{N}$ is a consistent estimate of $S_{w}$. [See L. P. Hansen (1982) or Newey and West (1987) for a definition of $S_{w}$.] Under the appropriate regularity conditions, (A.4) is asymptotically $\chi^{2}(7)$. This statistic is analogous to the Wald statistic in that it only uses the unrestricted estimates. The $\chi^{2}(1)$ statistics reported in the section 4 tables are based on this restriction:

$$
\mathrm{a}^{\mathrm{i}}(\tilde{\pi}) \equiv\left[0, \ldots, 0, \nu_{\mathrm{i}}, 0, \ldots, 0\right]^{\prime}=0 .
$$

All of these tests are conditional on the maintained values of $\beta, \gamma_{1}$, and $\delta$ as well as the estimates of the autocorrelation coefficients and innovation variances of the tax processes. When cross-correlations instead of relative variabilities are being tested, the moment restrictions take on the form

$$
\begin{aligned}
& \text { E[lqmom } \left.{ }_{\mathrm{i}}-(\mathrm{x}(\mathrm{i}))\left(\ln \left(\mathrm{y}_{\mathrm{t}} / \mathrm{y}_{\mathrm{t}-1}\right)-\lambda\right) /\left(\sigma_{\mathrm{gy}} \sigma_{\mathrm{gx}(\mathrm{i})}\right)-\nu_{\mathrm{i}}\right]=0, \\
& \text { for } \mathrm{i}=1,4,
\end{aligned}
$$

where

$$
\begin{aligned}
\mathrm{x}_{\mathrm{t}}= & {\left[\ln \left(\mathrm{cp}_{\mathrm{t}} / \mathrm{cp}_{\mathrm{t}-1}\right)-\lambda, \ln \left(\mathrm{dk}_{\mathrm{t}} / \mathrm{dk}_{\mathrm{t}-1}\right)-\lambda, \ln \left(\mathrm{y}_{\mathrm{t}} \mathrm{n}_{\mathrm{t}-1} /\left\{\mathrm{n}_{\mathrm{t}} \mathrm{y}_{\mathrm{t}-1}\right\}\right)-\lambda,\right.} \\
& \left.\ln \left(\mathrm{k}_{\mathrm{t}} / \mathrm{k}_{\mathrm{t}-1}\right)-\lambda\right],
\end{aligned}
$$




$$
\sigma_{g x(i)}=\frac{1}{N} \sum_{t=1}^{N}\left[\ln \left(x(i) / x(i)_{t-1}\right)-\lambda\right]^{2}
$$

for cross-correlations with output. The restrictions for cross-correlations with hours are calculated in an analogous way. 


\section{References}

Aschauer, D. A., 1985, Fiscal policy and aggregate demand, American Economic Review 75, 117-27.

Barro, R. J. and C. Sahasakul, 1983, Measuring the average marginal tax rate from the individual income tax, Journal of Business 56, 419-52.

Barsky, R. B. and G. Solon, 1989, Real wages over the business cycle, NBER working paper 2888 (National Bureau of Economic Research, Cambridge, MA).

Bencivenga, V. R., 1992, An econometric study of hours and output variation with preference shocks, International Economic Review 33, 449-71.

Benhabib, J., R. Rogerson, and R. Wright, 1991, Homework in macroeconomics: Household production and aggregate fluctuations, Journal of Political Economy 99, 1166-87.

Bizer, D. S. and K. L. Judd, 1989, Taxation and uncertainty, American Economic Review (Papers and Proceedings) 79, 331-36.

Bodkin, R. G., 1969, Real wages and cyclical variations in employment: A reexamination of the evidence, Canadian Journal of Economics 2, 353-74.

Braun, R. A., 1990, The dynamic interaction of distortionary taxes and aggregate variables in postwar U.S. data, Ph.D. dissertation (Carnegie Melion University, Pittsburgh, PA).

Burnside, C., M. S. Eichenbaum, and S. T. Rebelo, 1990, Labor hoarding and the business cycle, NBER working paper 3556 (National Bureau of Economic Research, Cambridge, MA). 
Burtless, G., 1986, The work response to a guaranteed income: A survey of experimental evidence, in: A. H. Munnell, ed., Lessons from the income maintenance experiments: Proceedings of a conference held in September 1986, sponsored by Federal Reserve Bank of Boston and Brookings Institution, Conference Series 30 (Federal Reserve Bank of Boston, Boston, MA) $22-52$.

Cassou, S., 1990, Welfare costs of stabilization, Manuscript (State University of New York, Stony Brook, NY).

Chang, L., 1992, Business cycles with distorting taxes and disaggregated capital markets, Manuscript (Rutgers, Newark, NJ).

Chari, V. V., L. J. Christiano, and P. J. Kehoe, 1991, Optimal fiscal and monetary policy: Some recent results, Journal of Money, Credit, and Banking 23, Part 2, 519-39.

Christiano, L. J., 1987, Technical appendix to "Why does inventory investment fluctuate so much?," Research Department working paper 380 (Federal Reserve Bank of Minneapolis, Minneapolis, MN).

Christiano, L. J., 1988, Why does inventory investment fluctuate so much?, Journal of Monetary Economics 21, 247-80.

Christiano, L. J. and M. S. Eichenbaum, 1992, Current real-business-cycle theories and aggregate labor market fluctuations, American Economic Review 82, $430-50$.

Cooley, T. F., and G. D. Hansen, 1991, Tax distortions in a neoclassical monetary economy, Discussion paper 38 (Institute for Empirical Macroeconomics, Federal Reserve Bank of Minneapolis, Minneapolis, MN). 
Eckstein, Z. and K. I. Wolpin, 1989, Dynamic labour force participation of married women and endogenous work experience, Review of Economic Studies 56, $375-90$.

Eichenbaum, M. S., L. P. Hansen, and K. J. Singleton, 1988, A time series analysis of representative agent models of consumption and leisure choice under uncertainty, Quarterly Journal of Economics 103, 51-78.

Geary, P. T. and J. Kennan, 1982, The employment-real wage relationship: An international study, Journal of Political Economy 90, 854-71.

Greenwood, J. and G. W. Huffman, 1991, Tax analysis in a real-business-cycle model: On measuring Harberger triangles and Okun gaps, Journal of Monetary Economics 27, 167-90.

Hansen, G. D., 1985, Indivisible labor and the business cycle, Journal of Monetary Economics 16, 309-27.

Hansen, L. P., 1982, Large sample properties of generalized method of moments estimators, Econometrica 50, 1029-54.

Jorgenson, D. W. and M. A. Sullivan, 1981, Inflation and corporate capital recovery, in: C. R. Hulten, ed., Depreciation, inflation, and the taxation of income from capital (Urban Institute, Washington, DC) 171-237.

Judd, K. L., 1987, The welfare cost of factor taxation in a perfect-foresight model, Journal of Political Economy 95, 675-709.

King, R. G., C. I. Plosser, and S. T. Rebelo, 1988, Production, growth and business cycles: II. New directions, Journal of Monetary Economics 21, 309-41.

Kormendi, R. C., 1983, Government debt, government spending, and private sector behavior, American Economic Review 73, 994-1010. 
Kydland, F. E. and E. C. Prescott, 1982, Time to build and aggregate fluctuations, Econometrica 50, 1345-70.

Long, J. B. and C. I. Plosser, 1983, Real business cycles, Journal of Political Economy $91,39-69$.

McGrattan, E., 1991, The macroeconomic effects of distortionary taxation, Discussion paper 37 (Institute for Empirical Macroeconomics, Federal Reserve Bank of Minneapolis, Minneapolis, MN).

Musgrave, J. C., 1980, Government-owned fixed capital in the United States, 1925-79, Survey of Current Business 60, 33-43.

Newey, W. K. and K. D. West, 1987, A simple, positive semi-definite, heteroskedasticity and autocorrelation consistent covariance matrix, Econometrica $55,703-8$.

Prescott, E. C., 1986, Theory ahead of business cycle measurement, CarnegieRochester Conference Series on Public Policy 25, 11-44.

Rogerson, R. and R. D. Wright, 1988, Involuntary unemployment in economies with efficient risk sharing, Journal of Monetary Economics 22, 501-15.

Sargent, T. J., 1984, Autoregressions, expectations, and advice, American Economic Review 74, 408-15.

Vaughn, D. R., 1970, A nonrecursive algorithm for the discrete Ricatti equation, IEEE Transactions on Automatic Control 15, 597-99. 
Table 1

Estimates of the model's structural parameters under three types of taxes; annual frequencies. ${ }^{a}$

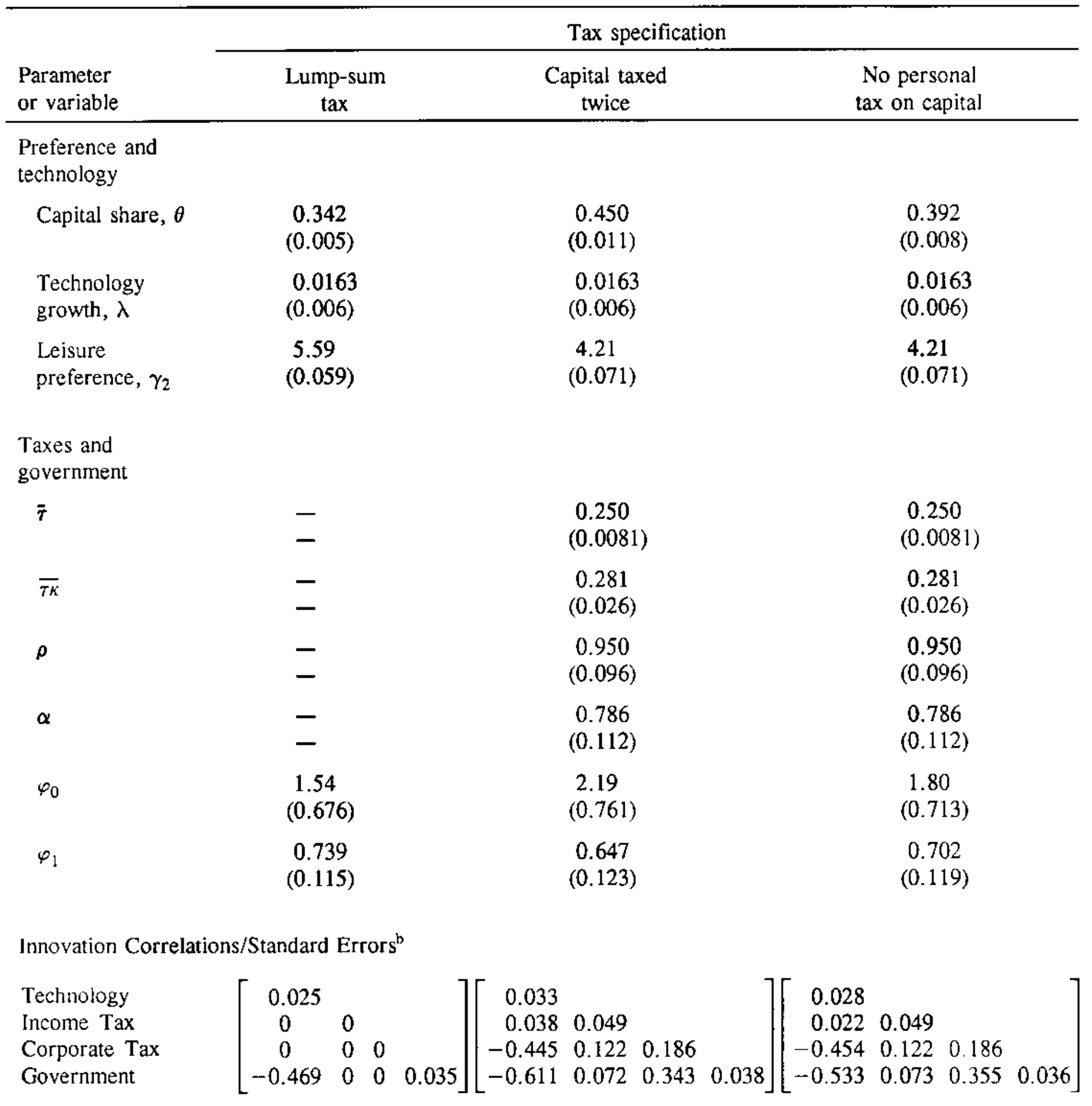

${ }^{\text {a } T h e s e ~ e s t i m a t e s ~ w e r e ~ c a l c u l a t e d ~ u s i n g ~ e q s . ~(19)-(26) . ~ T h e ~ s t a n d a r d ~ e r r o r s ~(i n ~ p a r e n t h e s e s) ~ w e r e ~ c a l c u l a t e d ~ u s i n g ~}$ a Newey-West covariance estimator with three autocovariances. The sample period is 1956-80.

${ }^{b}$ These matrices present the standard errors (diagonal terms) and correlations (off-diagonal terms) for the innovation to the variable listed on the left. 
Standard deviations of variables relative to that of output; predictions of the model under three types of taxes vs. U.S. data. ${ }^{a}$

\begin{tabular}{|c|c|c|c|c|c|c|c|}
\hline \multirow[b]{3}{*}{ Variable } & \multicolumn{6}{|c|}{ Tax specification } & \multirow{3}{*}{$\begin{array}{c}\text { U.S. } \\
\text { annual data } \\
1956-80\end{array}$} \\
\hline & \multicolumn{2}{|c|}{ Lump-sum tax } & \multicolumn{2}{|c|}{ Capital taxed twice } & \multicolumn{2}{|c|}{$\begin{array}{l}\text { No personal } \\
\text { tax on capital }\end{array}$} & \\
\hline & Moment & $\chi^{2}(1)$ & Moment & $\chi^{2}(1)$ & Moment & $\chi^{2}(1)$ & \\
\hline S.D. of output & 0.022 & $\begin{array}{c}2.15 \\
(0.143)\end{array}$ & 0.025 & $\begin{array}{c}0.179 \\
(0.673)\end{array}$ & 0.026 & $\begin{array}{c}0.054 \\
(0.815)\end{array}$ & $\begin{array}{c}0.027 \\
{[0.003]}\end{array}$ \\
\hline \multicolumn{8}{|c|}{ S.D. of variable relative to output } \\
\hline - Hours & 0.372 & $\begin{array}{l}22.4 \\
(0.000)\end{array}$ & 0.951 & $\begin{array}{c}0.531 \\
(0.466)\end{array}$ & 0.870 & $\begin{array}{c}0.001 \\
(0.976)\end{array}$ & $\begin{array}{c}0.867 \\
{[0.120]}\end{array}$ \\
\hline - Investment & 2.20 & $\begin{array}{c}0.735 \\
(0.391)\end{array}$ & 2.66 & $\begin{array}{c}3.28 \\
(0.070)\end{array}$ & 2.71 & $\begin{array}{l}3.10 \\
(0.078)\end{array}$ & $\begin{array}{l}2.08 \\
{[0.114]}\end{array}$ \\
\hline - Private consumption & 0.692 & $\begin{array}{l}12.64 \\
(0.000)\end{array}$ & 0.709 & $\begin{array}{l}12.73 \\
(0.000)\end{array}$ & 0.669 & $\begin{array}{c}4.83 \\
(0.028)\end{array}$ & $\begin{array}{c}0.497 \\
{[0.020]}\end{array}$ \\
\hline - Average productivity & 0.683 & $\begin{array}{c}0.928 \\
(0.335)\end{array}$ & 0.763 & $\begin{array}{c}2.77 \\
(0.096)\end{array}$ & 0.656 & $\begin{array}{c}0.373 \\
(0.541)\end{array}$ & $\begin{array}{c}0.609 \\
{[0.072]}\end{array}$ \\
\hline - Government purchases & 1.61 & $\begin{array}{c}0.872 \\
(0.350)\end{array}$ & 1.43 & $\begin{array}{c}0.172 \\
(0.679)\end{array}$ & 1.36 & $\begin{array}{c}0.062 \\
(0.803)\end{array}$ & $\begin{array}{l}1.27 \\
{[0.176]}\end{array}$ \\
\hline - Capital stock & 0.370 & $\begin{array}{c}0.241 \\
(0.623)\end{array}$ & 0.451 & $\begin{array}{l}1.38 \\
(0.241)\end{array}$ & 0.419 & $\begin{array}{c}0.940 \\
(0.332)\end{array}$ & $\begin{array}{c}0.336 \\
{[0.072]}\end{array}$ \\
\hline$x^{2}(7)^{b}$ & \multicolumn{2}{|c|}{$\begin{array}{l}51.68 \\
(0.000)\end{array}$} & \multicolumn{2}{|c|}{$\begin{array}{l}39.3 \\
(0.000)\end{array}$} & \multicolumn{2}{|c|}{$\begin{array}{l}26.3 \\
(0.000)\end{array}$} & \\
\hline
\end{tabular}

${ }^{\text {a }}$ This table reports population moments from the three estimated specifications and the analogous statistics (and their standard errors in brackets) calculated using annual U.S. data running from 1956 to 1980 . All moments are calculated in terms of variables expressed in log growth rates. Also here are $\chi^{2}$ (1) statistics (and their p-values in parentheses) for testing the null hypothesis that the statistic predicted by the model equals the corresponding value for the data in the last column.

${ }^{\mathrm{b}}$ This statistic tests the joint null hypothesis that all the above moments equal the corresponding values for the data in the last column. 
Table 3

Contemporaneous correlations; predictions of the model under three types of taxes vs. U.S. data. ${ }^{\text {a }}$

\begin{tabular}{|c|c|c|c|c|c|c|c|c|}
\hline \multirow{3}{*}{$\begin{array}{l}\text { Correlations of } \\
\text { variable with }\end{array}$} & \multirow[b]{3}{*}{ Variable } & \multicolumn{6}{|c|}{ Tax specification } & \multirow{3}{*}{$\begin{array}{c}\text { U.S. } \\
\text { annual data } \\
1956-80\end{array}$} \\
\hline & & \multicolumn{2}{|c|}{ Lump-sum tax } & \multicolumn{2}{|c|}{ Capital taxed twice } & \multicolumn{2}{|c|}{$\begin{array}{l}\text { No personal } \\
\text { tax on capital }\end{array}$} & \\
\hline & & Moment & $x^{2}(1)$ & Moment & $\chi^{2}(1)$ & Moment & $\chi^{2}(1)$ & \\
\hline \multicolumn{9}{|l|}{ A. Output } \\
\hline & Hours $^{\mathrm{b}}$ & 0.893 & - & 0.687 & - & 0.757 & - & $\begin{array}{c}0.796 \\
{[0.057]}\end{array}$ \\
\hline & Investment & 0.969 & $\begin{array}{c}0.027 \\
(0.869)\end{array}$ & 0.911 & $\begin{array}{c}0.007 \\
(0.935)\end{array}$ & 0.926 & $\begin{array}{c}0.000 \\
(0.986)\end{array}$ & $\begin{array}{c}0.930 \\
{[0.030]}\end{array}$ \\
\hline & Private consumption & 0.886 & $\begin{array}{c}0.039 \\
(0.844)\end{array}$ & 0.763 & $\begin{array}{c}0.098 \\
(0.754)\end{array}$ & 0.762 & $\begin{array}{c}0.096 \\
(0.757)\end{array}$ & $\begin{array}{c}0.837 \\
{[0.056]}\end{array}$ \\
\hline & Average productivity & 0.976 & $\begin{array}{l}3.19 \\
(0.074)\end{array}$ & 0.450 & $\begin{array}{c}0.053 \\
(0.817)\end{array}$ & 0.518 & $\begin{array}{c}0.001 \\
(0.972)\end{array}$ & $\begin{array}{c}0.509 \\
{[0.152]}\end{array}$ \\
\hline & Government purchases & 0.346 & $\begin{array}{c}0.243 \\
(0.622)\end{array}$ & 0.249 & $\begin{array}{c}0.004 \\
(0.948)\end{array}$ & 0.237 & $\begin{array}{c}0.020 \\
(0.888)\end{array}$ & $\begin{array}{c}0.260 \\
{[0.144]}\end{array}$ \\
\hline & Capital stock & 0.061 & $\begin{array}{c}0.325 \\
(0.569)\end{array}$ & 0.112 & $\begin{array}{c}0.082 \\
(0.775)\end{array}$ & 0.055 & $\begin{array}{c}0.347 \\
(0.556)\end{array}$ & $\begin{array}{c}0.168 \\
{[0.197]}\end{array}$ \\
\hline & $\chi^{2}(5)$ & \multicolumn{2}{|c|}{$\begin{array}{c}8.73 \\
(0.120) \\
\end{array}$} & \multicolumn{2}{|c|}{$\begin{array}{c}0.301 \\
(0.998)\end{array}$} & \multicolumn{2}{|c|}{$\begin{array}{c}0.475 \\
(0.993)\end{array}$} & \\
\hline \multicolumn{9}{|l|}{ B. Hours } \\
\hline & Investment & 0.910 & $\begin{array}{c}0.520 \\
(0.471)\end{array}$ & 0.831 & $\begin{array}{c}0.069 \\
(0.792)\end{array}$ & 0.826 & $\begin{array}{c}0.051 \\
(0.821)\end{array}$ & $\begin{array}{c}0.784 \\
{[0.053]}\end{array}$ \\
\hline & Private consumption & 0.611 & $\begin{array}{c}0.020 \\
(0.887)\end{array}$ & 0.259 & $\begin{array}{c}3.24 \\
(0.072)\end{array}$ & 0.420 & $\begin{array}{c}0.935 \\
(0.334)\end{array}$ & $\begin{array}{c}0.638 \\
{[0.094]}\end{array}$ \\
\hline & Average productivity & 0.776 & $\begin{array}{l}24.4 \\
(0.000)\end{array}$ & -0.337 & $\begin{array}{c}1.51 \\
(0.219)\end{array}$ & -0.165 & $\begin{array}{c}0.062 \\
(0.081)\end{array}$ & $\begin{array}{c}-0.116 \\
{[0.159]}\end{array}$ \\
\hline & Government purchases & 0.461 & $\begin{array}{c}3.23 \\
(0.072)\end{array}$ & 0.001 & $\begin{array}{c}0.209 \\
(0.648)\end{array}$ & 0.037 & $\begin{array}{c}0.081 \\
(0.776)\end{array}$ & $\begin{array}{c}0.093 \\
{[0.199]}\end{array}$ \\
\hline & Capital stock & -0.321 & $\begin{array}{c}6.77 \\
(0.009)\end{array}$ & -0.201 & $\begin{array}{l}3.78 \\
(0.052)\end{array}$ & -0.228 & $\begin{array}{l}4.50 \\
(0.034)\end{array}$ & $\begin{array}{c}0.262 \\
{[0.226]}\end{array}$ \\
\hline & $\chi^{2}(5)$ & \multicolumn{2}{|c|}{$\begin{array}{l}100.39 \\
(0.000)\end{array}$} & \multicolumn{2}{|c|}{$\begin{array}{l}7.39 \\
(0.193)\end{array}$} & \multicolumn{2}{|c|}{$\begin{array}{l}7.17 \\
(0.208)\end{array}$} & \\
\hline
\end{tabular}

${ }^{a}$ See footnotes to table 2 .

${ }^{\mathrm{b}}$ A rank problem prohibited testing this restriction jointly with the output/average productivity correlation. 
Fig. 1. Responses to a temporary $1 \%$ increase in the taxes on capital income (dashed lines) and personal income (solid lines); for the specification with capital taxed twice. 
Output

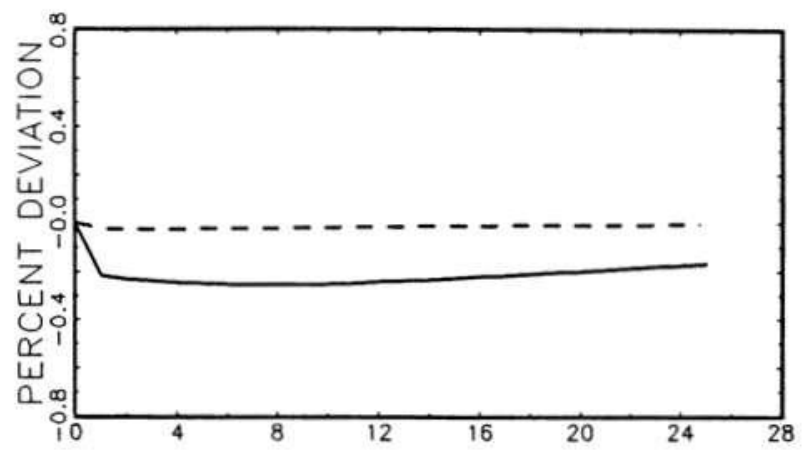

Employment

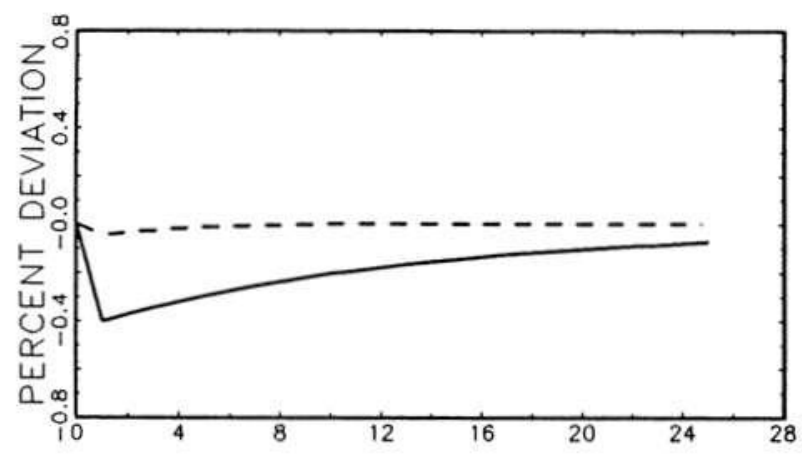

Investment

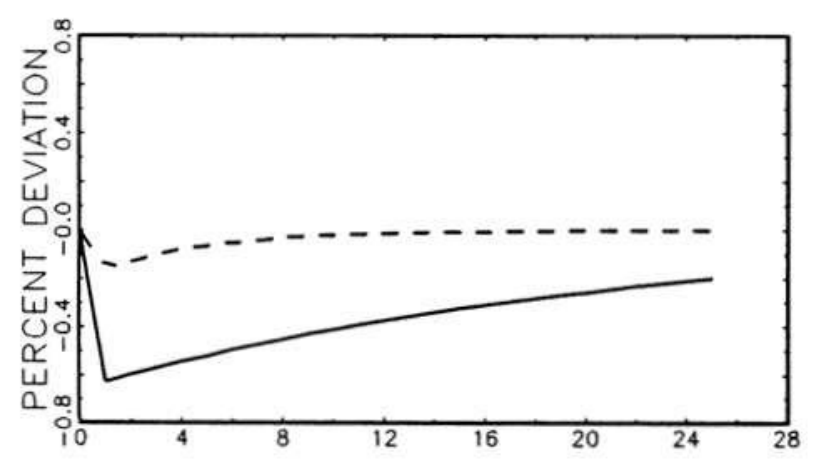

Government Revenue

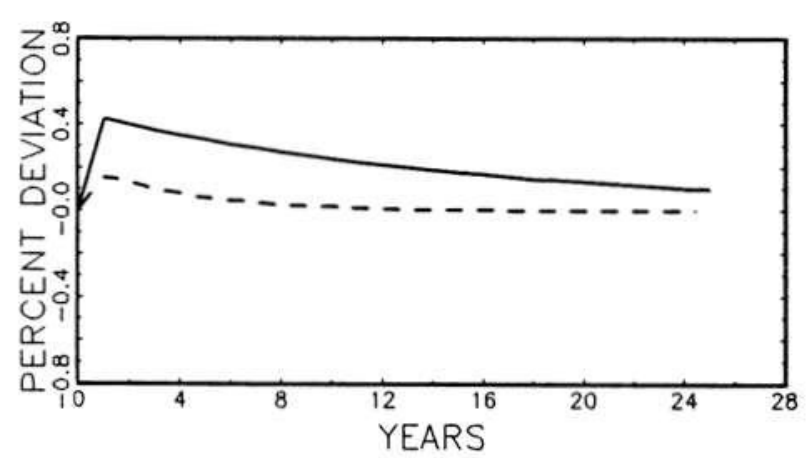

Private Consumption
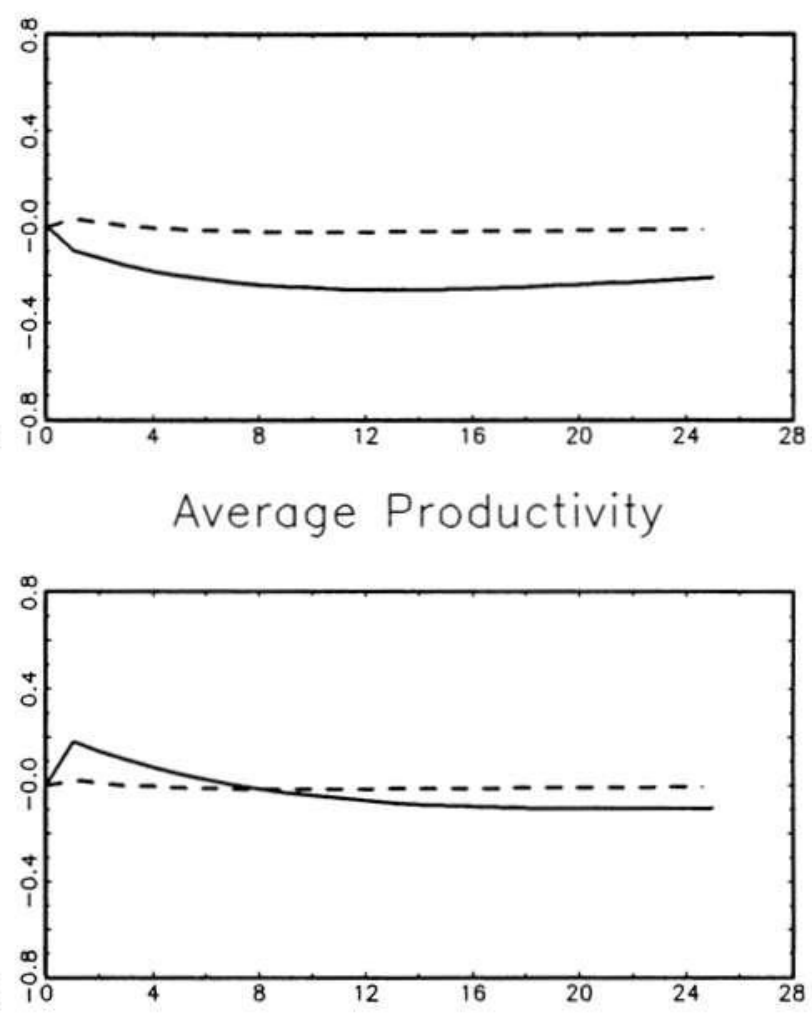

After-Tax Wage Rate
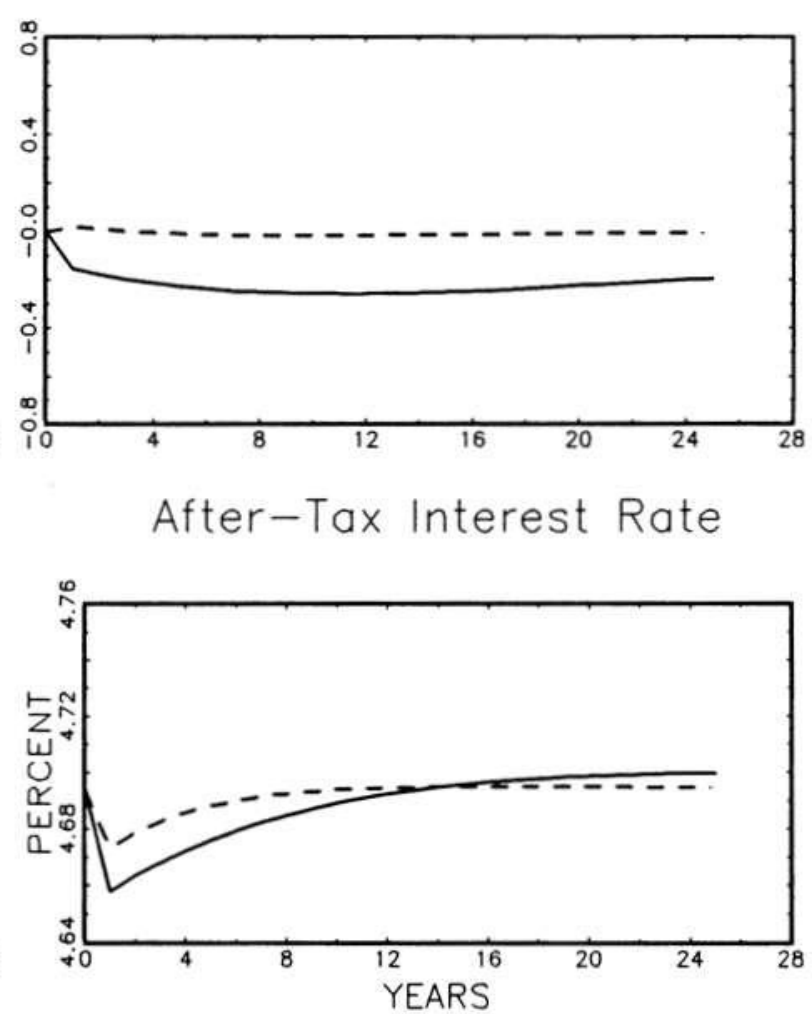